Jurnal Penelitian Perawat Profesional

Volume 3 Nomor 1, Februari 2021

e-ISSN 2715-6885; p-ISSN 2714-9757

http://jurnal.globalhealthsciencegroup.com/index.php/JPPP

\title{
TERAPI PADA DM TIPE 1
}

\section{Rivaldi marzel}

Fakultas Kedokteran, Universitas Lampung, Jl. Prof. DR. Ir. Sumatri Brojonegoro No.1, Gedong Meneng, Kec. Rajabasa, Kota Bandar Lampung, Lampung, Indonesia 35145 rivaldi.marzel26@gmail.com (+6283181815609)

\begin{abstract}
ABSTRAK
Diabetes melitus atau DM merupakan penyakit gangguan kronis dalam metabolisme protein, lemak, dan karbohidrat. DM digambarkan sebagai peningkatan glukosa darah setelah semua jenis makan.. Pada tahun 2019 International Diabetes Federation memperkirakan ada 463 juta penderita DM di seluruh dunia. Tujuan dilakukannya literature review ini adalah untuk membahas tatalaksana yang tepat pada kasus diabetes melitus tipe 1 . Sumber referensi yang digunakan untuk menyusun tulisan ini meliputi 20 artikel yang didapat dengan melakukan literature searching di Sumber NCBI, Google scholar dan 4 buku yang semuanya dipublikasikan dalam rentang tahun 2000-2020. Literature sarching tersebut dilakukan dengan menggunakan kata kunci Diabetes, diabetes melitus tipe 1, tatalaksana dan filter berupa rentang publikasi tahun 2000-2020. Hasil yang ditemukan dari literature searching ini adalah 9897 artikel yang kemudian dipilih 20 artikel dan 4 buku berdasarkan informasi yang dibutuhkan. Referensi yang telah didapatkan kemudian dianalisis dengan metode systematic literature review yang mencakup kegiatan mengumpulkan, mengevaluasi, dan mengembangkan penelitian dengan topik tertentu secara sistematis. Hasil literature review in menunjukkan bahwa tatalaksana pengelolaan DM tipe-1 dilakukan dengan beberapa penangaan, yaitu dengan pemberian insulin, pengaturan makan, olahraga,dan edukasi, yang didukung oleh pemantauan mandiri.
\end{abstract}

Kata kunci: diabetes; diabetes melitus tipe1; tatalaksana

\section{MANAGEMENT OF TYPE 1 DIABETES MELLITUS}

\begin{abstract}
Diabetes mellitus or DM is a chronic disorder in the metabolism of protein, fat and carbohydrates. DM is described as an increase in blood glucose after all types of eating. In 2019 the International Diabetes Federation estimated there were 463 million people with diabetes worldwide. The purpose of this literature review is to discuss the appropriate management of type 1 diabetes mellitus. The reference sources used to compile this paper include 20 articles obtained by conducting literature searches on NCBI sources, Google scholarships and 4 books, all of which were published in a span of years 2000-2020. The sarching literature was carried out using the keywords Diabetes, type 1 diabetes mellitus, management and filters in the form of publication ranges from 2000-2020. The results found from this literature searching were 9897 articles, which were then selected 20 articles and 4 books based on the information needed. The references that have been obtained are then analyzed using the systematic literature review method which includes the activities of collecting, evaluating, and systematically developing research with certain topics. The results of this literature review show that the management of type-1 diabetes mellitus is carried out with several measures, namely by giving insulin, eating arrangements, exercise, and education, which is supported by independent monitoring (home monitoring).
\end{abstract}

Keywords: diabetess; type 1 diabetes mellitus; therapy 


\section{PENDAHULUAN}

Diabetes melitus adalah suatu kelompok gangguan metabolik dengan karakteristik hiperglikemia atau kadar glukosa daraha yang tingi yang dapat terjadi karena kelainan sekresi insulin, kerja insulin atau keduaduanya.Hiperglikemia kronik pada Diabetes berhubungan dengan kerusakan jangka panjang, disfungsi dan kegagalan beberapa organ tubuh, terutama mata, ginjal, syaraf, jantung dan pembuluh darah (Priyono \& bettiza, 2010; American Diabetes Association (ADA) 2004). Secara global, diperkirakan 422 juta orang dewasa hidup dengan diabetes pada tahun 2014, dibandingkan dengan 108 juta pada tahun 1980. Prevalensi diabetes di dunia (dengan usia yang distandarisasi) telah meningkat hampir dua kali lipat sejak tahun 1980, meningkat dari 4,7\% menjadi $8,5 \%$ pada populasi orang dewasa. Kasus diabetes melitus di Indonesia menurut Riset Kesehatan Dasar (Riskesdas) memperlihatkan peningkatan angka prevalensi yang cukup signifikan, yaitu dari $6,9 \%$ di tahun 2013 menjadi 8,5\% di tahun 2018; sehingga estimasi jumlah penderita di Indonesia mencapai lebih dari 16 juta orang (Kementrian Kesehatan RI, 2018). Ikatan Dokter Anak Indonesia (IDAI) pada tahun 2018 melaporkan ada 1220 anak penyandang DM tipe-1 di Indonesia.

Klasifikasi diabetes ada beberapa jenis, yaitu Diabetes Mellitus yaitu Diabetes Mellitus Tipe I, Diabetes Mellitus Tipe II, Diabetes Mellitus Tipe Gestasional, dan Diabetes Mellitus Tipe Lainnya. Jenis Diabetes Mellitus yang paling banyak diderita adalah Diabetes Mellitus Tipe 2. Diabetes Mellitus Tipe 2 (DM Tipe 2) adalah penyakit gangguan metabolik yang di tandai oleh kenaikan gulah darah akibat penurunan sekresi insulin oleh sel beta pankreas dan atau ganguan fungsi insulin (resistensi insulin) (Trisnawati \& Setyorogo, 2013; Depkes, 2005).

Diabetes Mellitus (DM) tipe 1 atau yang dulu dikenal dengan nama Insulin Dependent Diabetes Mellitus (IDDM), terjadi karena kerusakan sel beta pankreas (reaksi autoimun). Sel beta pankreas merupakan satu-satunya sel tubuh yang menghasilkan insulin yang berfungsi untuk mengatur kadar glukosa dalam tubuh. Bila kerusakan sel beta pankreas telah mencapai $80-90 \%$ maka gejala DM mulai muncul. kerusakan sel ini lebih cepat terjadi pada anak-anak daripada dewasa. Sebagian besar penderita DM tipe 1 sebagian besar oleh karena proses autoimun dan sebagian kecil non autoimun. DM tipe 1 yang tidak diketahui penyebabnya juga disebut sebagai type 1 idiopathic dan ditemukan insulinopenia tanpa adanya petanda autoimun dan mudah sekali mengalami ketoasidosis. DM tipe 1 sebagian besar $(75 \%$ kasus $)$ terjadi sebelum usia 30 tahun dan DM tipe 1ni diperkirakan terjadi sekitar 5-10 \% dari seluruh kasus DM yang ada (American Diabetes Association, 2018).

Diabetes melitus tipe 1 dapat terjadi karena gangguan terhadap produksi insulin akibat kerusakan sel beta pankreas. Patofisiologi dari DM tipe 1 yakni adanya reaksi autoimun akibat peradangan pada sel beta. Hal ini menyebabkan timbulnya antibodi terhadap sel beta yang disebut Islet Cell Antibody (ICA). Reaksi antigen (sel beta) dengan antibodi ICA yang ditimbulkannya menyebabkan hancurnya sel beta. Selain karena autoimun, DM tipe 1 juga bisa disebabkan virus cocksakie, rubella, citomegalo virus (CMV), herpes dan lain-lain (Rustama dkk, 2010). 
Autoantibodi yang berkaitan dengan diabetes adalah glutamicacid decarboxylase 65 autoantibodies (GAD); tyrosine phosph ataselike insulinoma antigen 2 (IA2); insulin autoantibodies (IAA); dan $\beta$-cellspecific zinc transporter 8 autoantibodies (ZnT8). Ditemukannya satu atau lebih dari autoantibodi ini membantu konfirmasi diagnosis DM tipe-1 (IDAI, 2015).

Jumlah kasus DM tipe-1 pada anak dan remaja meningkat sekitar tujuh kali lipat dari 3,88 menjadi 28,19 per 100 juta penduduk pada tahun 2000 dan 2010. Data tahun 2003-2009 menunjukkan pada kelompok usia 10-14 tahun, proporsi perempuan dengan DM tipe 1 $(60 \%)$ lebih tinggi dibandingkan lakilaki (28,6\%). Pada tahun 2017, 71\% anak dengan DM tipe-1 pertama kali terdiagnosis dengan Ketoasidosis Diabetikum (KAD), meningkat dari tahun 2016 dan 2015, yaitu 63\%. Diduga masih banyak pasien DM tipe-1 yang tidak terdiagnosis atau salah diagnosis saat pertama kali berobat ke rumah sakit (Pulungan, 2019)

Orang yang menderita DM tipe 1 akan mengalami penuruna insulin post prandial, menurunnya insulin post prandial pada DM tipe 1 akan mempercepat proses katabolisme. Akibat glukosa yang tidak dapat memasuki hepar ataupun sel otot, maka akan dikirimkan sinyal bahwa tubuh kekurangan cadangan glukosa. Hal tersebut akan mengakibatkan tubuh memproduksi glukosa dengan berbagai cara, yaitu glikogenolisis (pemecahan glikogen dalam hepar untuk diubah menjadi glukosa) dan glukoneogenesis (proses pembentukan glukosa dari bahan selain karbohidrat). Kedua proses tersebut memperparah kondisi hiperglikemia yang sebelumnya telah terjadi. Akan tetapi karena glukosa dalam darah tidak dapat masuk ke dalam sel hepar ataupun sel otot, maka hepar akan berusaha lebih keras lagi untuk memproduksi glukosa. Selain itu juga akan terjadi proteolisis (proses pemecahan cadangan protein dalam sel otot menjadi asam amino) dan lipolisis (proses pemecahan lipid dalam jaringan adipose menjadi gliserol dan asam lemak bebas). Semua proses tersebut akhirnya akan menimbulkan kondisi hiperglikemia puasa (Rustama dkk, 2010).

Ginjal tidak dapat menyerap kembali semua glukosa yang tersaring keluar jika konsentrasi glukosa dalam darah cukup tinggi (>180 mg/dL), Hal ini mengakibatkan lolosnya glukosa tersebut dari proses rearbsorpsi ginjal dan glukosa akan muncul dalam urin (glukosuria). Ketika glukosa yang berlebihan diekskresikan ke urin, ekskresi ini akan disertai pengeluaran cairan dan elektrolit yang berlebihan pula. Keadaan ini dinamakan diuresis osmotik yang menyebabkan pasien mengalami peningkatan dalam berkemih (poliuria). Sebagai akibat dari kehilangan cairan yang berlebihan, pasien akan mengalami dehidrasi dan rasa haus (polidipsia) (Homenta, 2012).

Manifestasi klinis yang muncul pada penderita DM tipe 1 yaitu berupan poliuria (air kencing keluar banyak) dan polydipsia (rasa haus yang berlebih) yang disebabkan karena osmolalitas serum yang tinggi akibat kadar glukosa serum yang meningkat. Penderita DM tipe 1 juga akan mengalamai anoreksia dan polifagia (rasa lapar yang berlebih) yang terjadi karena glukosuria yang menyebabkan keseimbangan kalori negatif. Penderita DM tipe 1 akan mengalami keletihan (rasa cepat lelah) dan kelemahan yang disebabkan 
penggunaan glukosa oleh sel menurun. Pada kulit pasien DM tipe 1 akan mengalami kering, lesi kulit atau luka yang lambat sembuhnya, dan rasa gatal pada kulit. Sakit kepala, mengantuk, dan gangguan pada aktivitas disebabkan oleh kadar glukosa intrasel yang rendah, kram pada otot, iritabilitas, serta emosi yang labil akibat ketidak seimbangan elektrolit merupakan. Gangguan penglihatan seperti pemandangan kabur yang disebabkan karena pembengkakan akibat glukosa dan sensasi kesemutan atau kebas di tangan dan kaki yang disebabkan kerusakan jaringan saraf juga sering di alami oleh penderita DM tipe . Gangguan rasa nyaman dan nyeri pada abdomen pada penderita DM tipe 1 disebabkan karena neuropati otonom yang akan menimbulkan konstipasi. (Smeltzer et al, 2013)

Diagnosis DM ditegakkan atas dasar pemeriksaan kadar glukosa darah. Diagnosis tidak dapat ditegakkan atas dasar adanya glukosuria. Berbagai keluhan dapat ditemukan pada pasien diabetes. Keluhan klasik DM ada seperti poliuria, polidipsia, polifagia, dan penurunan berat badan yang tidak dapat dijelaskan sebabnya. Keluhan lain pula berupa lemah badan, kesemutan, gatal, mata kabur, dan disfungsi ereksi pada pria, serta pruritus vulvae pada wanita (PERKENI, 2011). Diagnosis DM dapat ditegakkan melalui tiga cara: 1. Jika keluhan klasik ditemukan, maka pemeriksaan glukosa plasma sewaktu $>200 \mathrm{mg} / \mathrm{dL}$ atau 2. glukosa plasma puasa $\geq 126 \mathrm{mg} / \mathrm{dL}$ sudah cukup untuk menegakkan diagnosis DM. 3. Tes toleransi glukosa oral (TTGO). Apabila hasil pemeriksaan tidak memenuhi kriteria normal atau DM, bergantung pada hasil yang diperoleh, maka dapat digolongkan ke dalam kelompok toleransi glukosa terganggu (TGT) atau glukosa darah puasa terganggu (GDPT).
Diagnosis TGT ditegakkan bila setelah pemeriksaan TTGO didapatkan glukosa plasma 2 jam setelah beban antara 140 $199 \mathrm{mg} / \mathrm{dL}$. Diagnosis GDPT pula ditegakkan bila setelah pemeriksaan glukosa plasma puasa didapatkan antara 100 - $125 \mathrm{mg} / \mathrm{dL}$ dan pemeriksaan TTGO gula darah 2 jam < $140 \mathrm{mg} / \mathrm{Dl}$ (Luwiharto \& Ginanti, 2020)

Diagnosis dari DM tipe 1 sering mengalami kesalahan dan keterlambatan. Pada beberapa penderita mulai timbulnya gejala sampai menjadi ketoasidosis dapat terjadi sangat cepat, sedangkan pada penderita yang lain dapat timbul secara lambat dapat dalam beberapa bulan. Akibat keterlambatan diagnosis, penderita DM tipe-1 akan memasuki fase ketoasidosis yang dapat berakibat fatal bagi penderita. Keterlambatan ini dapat juga terjadi karena penderit disangka menderita bronkopneumonia dengan asidosis atau syok berat (IDAI \& World Diabetes Foundation, 2015)

Diabetes mellitus tipe 1 atau Insulin Dependent Diabetes Mellitus (IDDM) merupakan penyakit yang terjadi sebagai akibat proses autoimun yang menyerang sel $\beta$ pankreas sehingga menyebabkan berkurangnya jumlah produksi hormon insulin (Agustira, 2019). Diabetes melitus tipe 1 merupakan penyakit yang dapat berakibat fatal jika tidak di tangani dengan tepat. Penatalaksanaan diabetes melitus tipe 1 menurut Perkeni (2015) dan kowalak (2011) di bagi menjadi terapi farmakologis dan non farmakologis. Terapi farmakologis pada DM tipe 1 berupa pemberian terapi antihiperglikemia dan pemberian insulin, dan juga dapat berupa kombinasi antihiperglikemia dengan insulin. Terapi non farmakologi pada DM tipe 1 berupa pengaturan pola 
makan dan gaya hidup yang sehat (WHO, 2016). Tujuan dilakukannya penulisan literature review ini adalah untuk mengetahui tatalaksana yang tepat pada kasus DM tipe 1. Literature review ini perlu dilakukan agar memudahkan pembaca untuk mengetahui informasi terkait penanganan DM tipe 1

\section{METODE}

Penulisan artikel ini menggunakan metode literature review. Tulisan ini terbentuk atas informasi yang didapat dari 20 artikel dari jurnal indonesia dan international dan 4 buku yang dipublikasikan dalam rentang tahun 2000-2020. Referensi yang digunakan didapat dengan melakukan literature searching dari database NCBI dan Google Schoolar dengan kata kunci Diabetes Mellitus ; Type 1 Diabetes Mellitus ; Therapy dan filter berupa rentang publikasi tahun 2000-2020. Hasil yang ditemukan dari literature searching ini adalah 9897 artikel yang kemudian dipilih 20 artikel dan 4 buku berdasarkan informasi yang dibutuhkan. Artikel terpilih kemudian dianalisis dengan metode systemic literature review yang mencakup aktivitas pengumpulan, evaluasi, dan pengembangan penelitian dengan fokus tertentu.

\section{HASIL}

Diabetes melitus tipe 1 merupakan suatu penyakit yang tidak dapat disembuhkan, akan tetapi dengan tata laksana dan pemantauan yang adekuat anak dapat memiliki kualitas hidup yang baik. Tujuan dari tatalaksana atau terapi pada DM tipe-1 adalah untuk mencapai kontrol metabolik yang optimal, mencegah komplikasi akut, mencegah komplikasi jangka panjang mikrovaskular dan makrovaskular, serta membantu psikologis penderita dan keluarga. Lima pilar tata laksana DM tipe-1 pada penderita adalah injeksi insulin, pemantauan gula darah, nutrisi, aktivitas fisik, serta edukasi. Dalam menangani DM tipe-1, dibutuhkan pendekatan holistik dari tim tenaga kesehatan terintegrasi yang terdiri atas dokter endokrinologi, ahli gizi, psikiater atau psikolog dan, edukator DM (Pulungan 2019) . Prinsip penanganan Diabates Melitus secara umum ada lima sesuai dengan Konsensus Pengelolaan DM di Indonesia tahun 2006 adalah untuk meningkatkan kualitas hidup pasien DM. tujuan dari penatalaksanaan DM ada tujuan untuk jangka pendek, tujuan jangka panjang dan tujuan akhir. Tujuan jangka pendek dari tatalaksana DM adalah untuk menghilangkan keluhan dan gejala DM, mempertahankan rasa nyaman dan tercapainya target pengendalian glukosa darah. Tujuan jangka panjang berupa mencegah dan menghambat progresivitas penyulit mikroangiopati, makroangiopati dan neuropati. Sedangkan tujuan akhir dari pengelolaan DM adalah turunnya morbiditas dan mortalitas DM. Untuk mencapai tujuan tersebut perlu dilakukan pengendalian glukosa darah, tekanan darah, berat badan dan profil lipid, melalui pengelolaan pasien secara holistik dengan mengajarkan perawatan (Ambarwati, 2012).

Kriteria diagnosis DM (Ikatan Dokter Anak Indonesia, diadaptasi dari American Diabetes Association) Memenuhi salah satu kriteria:

1. Gejala klasik diabetes atau hiperglikemi dan glukosa plasma $\geq 200 \mathrm{mg} / \mathrm{dL}$ (11,1 mmol/L), atau

2. Glukosa puasa plasma $\geq 126 \mathrm{mg} / \mathrm{dL}$ (7,0 $\mathrm{mmol} / \mathrm{L})$, atau 
3. Glukosa 2 jam postprandial 200 $\mathrm{mg} / \mathrm{dL}(11,1 \mathrm{mmol} / \mathrm{L})$ dengan $\mathrm{Uji}$ Toleransi Glukosa Oral, atau

4. $\mathrm{HbA1c}>6,5 \%$ sesuai standar National Gylcohemoglobin Standardization Program (NGSP) pada labo atorium

\section{PEMBAHASAN}

komponen pengelolaan DM tipe-1 meliputi pemberian insulin, pengaturan makan, olahraga,dan edukasi, yang didukung oleh pemantauan mandiri (home monitoring). Keseluruhan komponen berjalan secara terintegrasi untuk mendapatkan kontrol metabolik yang baik. Dari faktor penderita juga terdapat beberapa kendala pencapaian kontrol metabolik yang baik. Faktor pendidikan, sosioekonomi dan kepercayaan merupakan beberapa faktor yang harus dipertimbangkan dalam pengelolaan penderita terutama dari segi edukasi (IDAI \& World Diabetes Foundation, 2015).

Insulin merupakan suatu elemen utama bagi kelangsungan hidup penderita DM tipe-1. Terapi insulin pertama kali digunakan pada tahun 1922, berupa insulin regular, diberikan sebelum makan dan ditambah sekali pada malam hari. Namun saat ini telah dikembangkan beberapa jenis insulin yang memungkinkan pemberian insulin dalam berbagai macam regimen (IDAI \& World Diabetes Foundation, 2015). Tujuan terapi insulin adalah menjamin kadar insulin yang cukup di dalam tubuh selama 24 jam untuk memenuhi kebutuhan metabolisme sebagai insulin basal maupun insulin koreksi dengan kadar yang lebih tinggi (bolus) akibat efek glikemik makanan (IDAI, 2017).

Insulin dikelompokan berdasarkan lama kerjanya yaitu cepat, pendek atau reguler, menengah, dan panjang.
Regimen insulin bersifat individual, yaitu menyesuaikan usia, berat badan, lama menderita, target kontrol glikemik, pola hidup, dan komorbiditas. Regimen yang disarankan adalah basal bolus yang diberikan dengan pompa atau insulin subkutan minimal 2 kali/hari dengan menggunakan insulin basal dan insulin kerja cepat atau pendek karena paling menyerupai sekresi insulin fisiologis (Paschou et al, 2018). Kebutuhan insulin basal harian adalah berkisar antara 30\% (jika menggunakan insulin reguler) sampai $50 \%$ (jika menggunakan insulin kerja cepat) dari total kebutuhan insulin. Pada pasien dengan insulin reguler, perbandingan insulin basal lebih kecil karena insulin reguler juga memberikan efek basal. Dosis insulin sisanya disesuaikan untuk dosis preprandial dengan insulin kerja cepat atau regular (Danne et al, 2018).

Terapi nutrisi atau pengaturan makanan yang baik dibutuhkan agar kondisi penderita DM tipe-1 optimal, serta mencegah komplikasi akut dan kronik. Prinsip dari terapi nutrisi adalah makan sehat. Pasien disarankan untuk mengonsumsi buah, sayur, produk susu, gandum utuh, dan daging rendah lemak dengan jumlah sesuai usia dan kebutuhan energi. Kebutuhan kalori per hari dapat dihitung berdasarkan berat badan ideal dan dan kecukupan kalori yang dianjurkan. Sebagai panduan, distribusi makronutrien adalah karbohidrat $45-50 \%$ energi, lemak $<35 \%$ energi, dan protein $15-20 \%$ energi. Pasien dan keluarga harus diajarkan untuk menyesuaikan dosis insulin berdasarkan konsumsi karbohidrat sehingga penderita lebih fleksibel dalam konsumsi karbohidrat. Regimen insulin dibagi ke dalam 3 penanganan untuk DM tipe 1 yaitu sistem konservatif, sistem intensif, dan sistem basal bolus. 
Tabel 1.

Jenis insulin (Maharani et al, 2004)

\begin{tabular}{lcccc}
\hline Jenis insulin & Tipe insulin & $\begin{array}{c}\text { Awitan } \\
(\text { jam })\end{array}$ & $\begin{array}{c}\text { Puncak } \\
\text { kerja (jam) }\end{array}$ & $\begin{array}{c}\text { Lama kerja } \\
\text { (jam) }\end{array}$ \\
\hline Kerja ultra pendek & $\begin{array}{c}\text { Insulin, lispro, } \\
\text { insulin, aspart }\end{array}$ & $5-15$ menit & $1-1,5$ & $3-4$ \\
\hline Kerja pendek & Regular, velosulin & $15-30$ menit & $1-3$ & $5-7$ \\
\hline Kerja menengah & $\begin{array}{c}\text { Lente, neutral } \\
\text { protamine }\end{array}$ & $2-4$ & $8-10$ & $18-24$ \\
\hline & Hagedon (NPH) & & & \\
\hline Kerja panjang & Ultra lente & $4-5$ & $8-14$ & $25-36$ \\
\hline & Ins. Glargine & $6-8$ & - & 24 \\
\hline
\end{tabular}

Regimen insulin sistem konservatif adalah pemberian insulin 2 atau $3 \mathrm{kali}$ perhari dengan pemantauan kadar gula darah di rumah yang longgar / tidak rutin, kontrol ke dokter setiap tiga bulan, dan tidak dapat mengubah dosis insulin sesuka hati. regimen intensif berartipemberian insulin minimal empat kali sehari disertai dengan pemantauan glukosa darah di rumah juga minimal empat kali sehari. Sistemn regimen basal bolus adalah pemberian insulin kerja panjang atau kerja menengah sebelum tidur malam (komponen basal) dan kemudian pemberian insulin kerja pendek setiap kali sebelum makan (Batubara et al, 2017)

sehingga penderita lebih fleksibel dalam konsumsi karbohidrat. Cara ini diketahui meningkatkan kontrol glikemik dan kualitas hidup (Smart, 2018). Pada regimen konvensional, pengaturan makan dengan memperhitungkan asupan dalam bentuk kalori sedangkan pada regimen basalbolus, pengaturan makan dengan memperhitungkan asupan dalam bentuk gram karbohidrat. Pemilihan jenis makanan dianjurkan karbohidrat dengan indeks glikemik dan glicemic load yang rendah (IDAI, 2017). Terapi nonfarmakologis untuk DM tipe 1 adalah berupa aktivitas fisik atau olahraga juga sangat penting untuk penderita DM tipe 1. Selain itu, aktivitas fisik dapat meningkatkan kepercayaan diri anak, mempertahankan berat badan ideal, meningkatkan metabolisme tubuh (IDAI, 2017).

Rekomendasi aktivitas fisik pada anak dengan DM tipe-1 sama dengan populasi umum, yaitu aktivitas $\geq 60$ menit setiap hari yang mencakup aktivitas aerobik, menguatkan otot, dan menguatkan tulang. Aktivitas aerobik sebaiknya tersering dilakukan, sementara aktvitas untuk menguatkan otot dan tulang dilakukan paling tidak 3 kali per minggu.

Beberapa kondisi yang harus diperhatikan sebelum aktivitas fisik adalah (1) peningkatan keton, kadar keton darah $\geq 1,5 \mathrm{mmol} / \mathrm{L}$ atau urin $2+$ merupakan kontraindikasi aktivitas fisik, (2) riwayat hipoglikemia, (3) pemantauan gula darah, anak sebaiknya mengukur gula darah sebelum, saat, dan setelah aktivitas fisik, (4) ketersediaan karbohidrat jika terjadi hipoglikemia, dan (5) keamanan dan komunikasi, sebagai contoh anak sebaiknya menggunakan identitas diabetes (Adolfsson et al, 2018). Asupan cairan juga perlu ditingkatkan sebelum, setelah, dan saat olahraga. Pada orang dewasa yang menderita DM dianjurkan latihan secara teratur (3-4 kali 
seminggu) selama kurang lebih 30 menit, yang sifatnya sesuai dengan CRIPE (Continous, Rhythmical, Interval, Progresive, Endurance Training) sesuai dengan kemampuan pasien. Sebagai contoh adalah olah raga ringan jalan kaki biasa selama 30 menit. Hindarkan kebiasaan hidup yang kurang gerak atau bermalasmalasan (Smart, 2018).

Pendidikan kesehatan atau edukasi sangat penting dalam pengelolaan DM untuk mendapatkan hasil yang optimal. Pendidikan kesehatan atau edukasi pada pasien DM sebaiknya dilakukan oleh semua pihak yang terkait dalam pengelolaan DM, seperti dokter, perawat, ahli gizi. Pendidikan kesehatan pencegahan primer harus diberikan kepada kelompok masyarakat resiko tinggi. Pendidikan kesehatan sekunder diberikan kepada kelompok pasien DM. Sedangkan pendidikan kesehatan untuk pencegahan tersier diberikan kepada pasien yang sudah mengidap DM dengan penyulit menahun (Ambarwati, 2012).

Edukasi yang diberikan adalah pemahaman tentang perjalanan penyakit, pentingnya pengendalian penyakit, komplikasi yang timbul dan resikonya, pentingnya intervensi obat dan pemantauan glukosa darah, cara mengatasi hipoglikemia, perlunya latihan fisik yang teratur, dan cara mempergunakan fasilitas kesehatan. Mendidik pasien bertujuan agar pasien dapat mengontrol gula darah, mengurangi komplikasi dan meningkatkan kemampuan merawat diri sendiri (Putra \& Berawi, 2015).

Edukasi/pendidikan merupakan unsur penting pengelolaan DM tipe 1, yang harus dilakukan secara terus menerus dan bertahap sesuai tingkat pengetahuan serta status sosial penderita/keluarga. Edukasi merupakan salah satu kunci kesuksesan tatalaksana diabetes mellitus. Edukasi terstruktur terbukti bermanfaat pada kontrol glikemik maupun aspek psikososial. Tujuan dari edukasi pada pasian DM tipe 1 adalah (1)Menimbulkan pengertian dan pemahaman mengenai penyakit dan komplikasinya. (2) Memotivasi penderita dan keluarganya agar patuh berobat. (3) Memberikan ketrampilan penanganan DM tipe-1. (4) Mengembangkan sikap positif terhadap penyakit sehingga tercermin dalam pola hidup sehari-hari. (5) Mencapai kontrol metabolik yang baik sehingga terhindar dari komplikasi. (6) Mengembangkan kemampuan untuk memberikan keputusan yang tepat dan logis dalam pengelolaan sehari-hari. (7) Menyadarkan penderita bahwa DM tipe-1 bukanlah penghalang untuk mencapai cita-cita (IDAI \& World Diabetes Foundation, 2015).

Diabetes melitus tipe 1 merupakan penyakit kronik dan memerlukan pengobatan seumur hidup, maka pasien serta keluarga harus dapat melakukan pemantauan kadar glukosa darah serta penyakitnya dirumah. Hali ini sangat diperlukan karena sangat menunjang upaya pencapaian normoglikemia. monitoring dapat dilakukan secara lansung (darah) dan secara tidak langsung (urin). Pemeriksaan glukosa darah secara lansung lebih tepat menggambarkan kadar glukosa pada saat pemeriksaan. Pemeriksaan adalam pemantauan sebaiknya dilakukan dengan teratur pada saat awal perjalanan penyakit, pada setiap penggantian dosis insulin atau pada saat sakit (Deliana, 2020).

Target kadar glukosa darah penderita harus tergantung pada keadaan individu 
penderita tersebut, berdasarkan usia, lama sakit diabetes, resiko hipoglikemia berat, adanya pernyakit kardiovaskuler, serta life expectancy. Target yang diharapkan ialah, untuk glukosa darah puasa antara $72-125 \mathrm{mg} / \mathrm{dl}$, dan 2 jam setelah makan antara $90-180 \mathrm{mg} / \mathrm{dL}$ (Imran, 2013).

\section{SIMPULAN}

Tatalaksana pengelolaan DM tipe-1 dilakukan dengan beberapa penangaan, yaitu dengan pemberian insulin, pengaturan makan, olahraga,dan edukasi, yang didukung oleh pemantauan mandiri (home monitoring). Keseluruhan komponen berjalan secara terintegrasi untuk mendapatkan kontrol metabolik yang baik.

Tabel 2.

Target Glukosa Darah Berdasarkan ISPAD dan IDF

\begin{tabular}{|c|c|c|c|c|}
\hline $\begin{array}{l}\text { Derajat } \\
\text { kontrol }\end{array}$ & $\begin{array}{c}\text { Ideal } \\
\text { (non diabetik) }\end{array}$ & Optimal & Suboptimal & Risiko tinggi \\
\hline $\begin{array}{l}\text { Glukosa } \\
\text { darah } \\
\text { sebelum } \\
\text { makan }\end{array}$ & $\begin{array}{c}65-100 \\
\mathrm{mg} / \mathrm{dL} \\
(3.6-5.6 \\
\mathrm{mmol} / \mathrm{L})\end{array}$ & $\begin{array}{c}90-145 \\
\mathrm{mg} / \mathrm{dL} \\
(5-8 \\
\mathrm{mmol} / \mathrm{L})\end{array}$ & $\begin{array}{l}>145 \mathrm{mg} / \mathrm{dL} \\
(>8 \mathrm{mmol} / \mathrm{L})\end{array}$ & $\begin{array}{l}>162 \mathrm{mg} / \mathrm{dL} \\
(>9 \mathrm{mmol} / \mathrm{L})\end{array}$ \\
\hline $\begin{array}{l}\text { Glukosa } \\
\text { darah } \\
\text { setelah } \\
\text { makan }\end{array}$ & $\begin{array}{c}80-126 \\
\mathrm{mg} / \mathrm{dL} \\
(4.5-7.0 \\
\mathrm{mmol} / \mathrm{L})\end{array}$ & $\begin{array}{c}90-180 \\
\mathrm{mg} / \mathrm{dL} \\
(5-10 \\
\mathrm{mmol} / \mathrm{L})\end{array}$ & $\begin{array}{l}180-250 \mathrm{mg} / \mathrm{dL} \\
(10-14 \mathrm{mmol} / \mathrm{L})\end{array}$ & $\begin{array}{c}>250 \mathrm{mg} / \mathrm{dL} \\
(>14 \mathrm{mmol} / \mathrm{L})\end{array}$ \\
\hline $\begin{array}{l}\text { Glukosa } \\
\text { darah } \\
\text { sebelum } \\
\text { tidur }\end{array}$ & $\begin{array}{c}80-100 \\
\mathrm{mg} / \mathrm{dL} \\
(4.0-5.6 \\
\mathrm{mmol} / \mathrm{L})\end{array}$ & $\begin{array}{c}120-180 \\
\mathrm{mg} / \mathrm{dL} \\
(6.7-10 \\
\mathrm{mmol} / \mathrm{L})\end{array}$ & $\begin{array}{c}<120 \mathrm{mg} / \mathrm{dL} \text { atau } \\
200 \mathrm{mg} / \mathrm{dL} \\
(<6.7 \mathrm{mmol} / \mathrm{L} \text { atau } \\
10-11 \\
\mathrm{mmol} / \mathrm{L}) \\
\end{array}$ & $\begin{array}{c}<80 \mathrm{mg} / \mathrm{dL} \text { atau } \\
>200 \mathrm{mg} / \mathrm{dL} \\
(<4.4 \mathrm{mmol} / \mathrm{L} \text { atau } \\
>11 \\
\mathrm{mmol} / \mathrm{L})\end{array}$ \\
\hline $\begin{array}{l}\text { Glukosa } \\
\text { darah } \\
\text { malam hari } \\
\text { saat } \\
\text { tidur } \\
\end{array}$ & $\begin{array}{c}65-100 \\
\mathrm{mg} / \mathrm{dL} \\
(3.6-5.6 \\
\mathrm{mmol} / \mathrm{L})\end{array}$ & $\begin{array}{c}80-162 \\
\mathrm{mg} / \mathrm{dL} \\
(4.5-9 \\
\mathrm{mmol} / \mathrm{L})\end{array}$ & $\begin{array}{c}<75 \mathrm{mg} / \mathrm{dL} \text { atau } \\
>162 \mathrm{mg} / \mathrm{dL} \\
(<4.3 \mathrm{mmol} / \mathrm{L} \text { atau } \\
>9 \\
\mathrm{mmol} / \mathrm{L}\end{array}$ & $\begin{array}{c}70 \mathrm{mg} / \mathrm{dL} \text { atau }>200 \\
\mathrm{mg} / \mathrm{dL} \\
(<4.0 \mathrm{mmol} / \mathrm{L} \text { atau } \\
>11 \\
\mathrm{mmol} / \mathrm{L})\end{array}$ \\
\hline
\end{tabular}

DAFTAR PUSTAKA

Acerini, C. (2018). clinical practice concensus guidelines: nutritional management in children and adolescents with diabetes. Pediatric Diabetes. ISPAD, 19, 136-54.

https://onlinelibrary.wiley.com/do i/abs/10.1111/pedi.12738

ADA. (2013) Standards of Medical Care in Diabetes -. Diabates Care, 36, Supp 1: S11 - 66.
https://doi.org/10.2337/dc13-S011

Agustira, A., Darwis, I., Graharti, R., Angraini, D. I. (2019). Tanaman Sambung Nyawa (Gynura procumbens) sebagai Antihiperglikemi. Medula, 9(2), 240-244.

https://juke.kedokteran.unila.ac.id /index.php/medula/article/view/23 88

Ambarwati, W. N. 2012. Konseling 
pencegahan dan penatalaksanaan penderita diabetes mellitus. Publikasi Ilmiah Universitas Muhammadiyah Surakarta, 2(1), 55-70.

http://hdl.handle.net/11617/2831

American Diabetes Association. (2018). Classification and diagnosis of diabetes mellitus. Diabetes Care, 41(Suppl 1), S13S27. https://doi.org/10.2337/dc18S002

Batubara, J. R. L., Tridjaja, B, Pulungan, A. P. (2017). Buku Ajar Endokrinologi. Edisi Kedua. Jakarta: Badan Penerbit Ikatan Dokter Anak Indonesia.

Danne, T., Phillip, M., Buckingham, B. A, Jarosz-Chobot, P., Saboo, B., Urakami T. (2018). ISPAD Clinical Practice Concensus Guidelines: Insulin treatment in children and adolescents with diabetes. Pediatric Diabetes, (19), 115-35.

https://doi.org/10.1111/j.1399544

8.2009.00578.x

Ikatan Dokter Anak Indonesia. (2017). Diagnosis dan Tata Laksana Diabetes Melitus Tipe-1 pada Anak dan Remaja. Jakarta. Unit Kerja Koordinasi Endokrinologi

Imran, A. (2013). Targets for Glycemic Control. Can J Diabetes, vol, 37, supp, $\quad 1 p, \quad \mathrm{~S} 31-\mathrm{S} 34$. https://doi.org/10.1016/j.jcjd.2013 .01 .016

Kemenkes. (2018). Riset kesehatan dasar. Jakarta: Badan Penelitian dan Pengembangan Kemenkes RI

Kemenkes RI. (2019). Profil Kesehatan Indonesia 2018. Diambil dari http://www.depkes.go.id/resource s/download/pusdatin/profilkesehat an- indonesia/Data-danInformasi_Profil-KesehatanIndonesia-2018.pdf

Kowalak, J. P., Welsh, W., Mayer, B. (2011). Buku Ajar Patofisiologi. Alih bahasa oleh Andry Hartono. Jakarta: EGC.

Luwiharto, J., Ginanti, P. D. (2020). Diabetes melitus. Prodia Occupational Health Institute. PT Prodia OHI International

Paschou, S. A., PapadopoulouMarketou, N., Chrousos, G. P., Kanaka-Gantenbein, C. (2018). type 1 diabetes mellitus pathogenesis. Endocrine Connections, (7), R3846.https://doi.org/10.1530/EC-17$\underline{0347}$

PERKENI. (2011). Konsensus Pengelolaan dan Pencegahan Diabetes Melitus Tipe 2 di Indonesia. Jakarta: PERKENI.

Pulungan, A. B., Annisa, D., Imada, S. (2019). Diabetes Melitus Tipe-1 pada Anak : Situasi di Indonesia dan Tata Laksana. Sari Pediatri, 20(6), 392-400. http://dx.doi.org/10.14238/sp20.6. 2019.392-400

Putra, W. A., Beraw,i K. N. (2015). Empat Pilar Penatalaksanaan Pasien Diabetes Mellitus Tipe 2. Jurnal Majority, 4(9), 8-12. http://juke.kedokteran.unila.ac.id/i ndex.php/majority/article/view/14 01

Rustama, D., Subardja, D., Oentario, M., Yati, N., Satriono., Harjantien, N., (2010). Diabetes 
Melitus, Buku Ajar Endokrinologi Anak. BP IDAI. Jakarta: 2010:162-3.

Smart, CE., Annan, F., Higgins, LA., Jelleryd, E., Lopez, M., Acerini, CL., (2018). ISPAD clinical practice concensus guidelines nutritional management in children and adolescents. The University of Newcastle Australia, $\quad$ 15(20). http://dx.doi.org/10.1111/pedi.121 $\underline{75}$

Smeltzer, S. C., Bare, B. G., Hinkle, J. L., Cheever, K. H., (2013). Keperawatan medikal bedah Brunnen \& Suddarth ed. 12, alih bahasa: Devi Y, Amelia K. editor edisi Bahasa Indonesia. Eka AM.
Jakarta: EGC

Trijaya B., Batubara, J. R. (2000). Konsensus nasional pengelolaan diabetes mellitus tipe-1 di Indonesia. UKK Endokrinologi IDAI. Jakarta

Trisnawati, S. K., \& Setyorogo, S. (2013). Faktor Risiko Kejadian Diabetes Melitus Tipe II Di Puskesmas Kecamatan Cengkareng Jakarta Barat Tahun 2012. Jurnal Ilmiah Kesehatan, $5(1)$, 6-11. http://fmipa.umri.ac.id/wpcontent/ uploads/2016/06/YUNI-INDRIFAKTOR-RESIKO-DM.pdf

WHO. (2016). Global Report on Diabetes. World Health Organization. In $W H O$ Geneva 
Jurnal Penelitian Perawat Profesional, Volume 3 No 1, Februari 2021 Hal 51 - 62 Global Health Science Group 